\title{
Kulturní plánování v kontextu městského a udržitelného rozvoje
}

\author{
Kateřina Vojtíšková - Markéta Poláková - Věra Patočková \\ Sociologický ústav AV ČR, v.v.i., 110 00, Praha 1, Jilská 1 \\ Do redakce doručeno 29. dubna 2015; k publikaci přijato 4. března 2016
}

Tato studie vznikla v rámci projektu „Sociální a institucionální podmíněnost rozvoje kultury a uchování kulturního dědictví v regionálním prostředí a její využití v efektivnější organizaci kulturních aktivit regionu“, který byl podpořen Ministerstvem kultury v rámci Programu aplikovaného výzkumu a vývoje národní a kulturní identity (NAKI), identifikační kód projektu: DF11P01OVV032.

\section{CULTURAL PLANNING IN THE CONTEXT OF URBAN AND SUSTAINABLE DEVELOPMENT}

ABSTRACT The aim of the paper is to introduce cultural planning as a cultural policy approach widespread abroad, which is also suitable for local governments in the Czech Republic. Cultural mapping is an integral part of cultural planning; it is applied in order to identify local cultural resources. The benefits of the cultural planning include broadening of the relationship between culture and other areas (cultural tourism, sport, and education), promotion of the local participation or visibility of the contribution of culture to the sustainable local and regional development.

KEY WORDS Cultural planning; cultural policy; cultural resources; sustainable development; urban development

ABSTRAKT Cílem textu je představit kulturní plánování jako kulturně politický přístup široce rozšířený v zahraničí, který je vhodný také pro místní samosprávy v České republice. Součástí kulturního plánování je kulturní mapování, v rámci kterého se identifikují místní kulturní zdroje. Mezi prŕnosy tohoto př́istupu k plánování patři prohlubování vztahů mezi kulturou a jinými oblastmi (kulturní cestovní ruch, sport, vzdělávání), podpora participace nebo zviditelnění prínosu kultury pro udržitelný místní a regionální rozvoj.

KLÍČOVÁ SLOVA Kulturní plánování; kulturní politika; kulturní zdroje; udržitelný rozvoj; městský rozvoj

\section{ÚVOD}

V českém kontextu se o kulturní politice jako součásti urbánní politiky př́liš nehovoří. Diskurz kulturního plánování se dosud neprosadil, ačkoli se v městském prostředí o kultuře stále více uvažuje jako o faktoru místního či regionálního rozvoje. Kulturní plánování vymezujeme jako inkluzivní, kulturně citlivý participativní proces $\mathrm{v}$ rámci lokálního a regionálního plánování, který vychází z širší definice kultury a zapojení místní komunity do plánovacího procesu (Bianchini 2013). Jeho významnou součástí je kulturní mapování, při němž dochází $\mathrm{k}$ identifikaci místních kulturních zdrojů. Tyto zdroje jsou pak strategicky a integrálně využívány pro rozvoj města a komunit (Mercer 2002; Evans - Foord 2008; Grogan - Mercer - Engwicht 1995).

Cílem článku je uvést kulturní plánování jako specifický koncepční kulturně politický př́stup, který si zaslouží pozornost jak v oblasti teorie, tak i praxe lokálního a regionálního rozvoje. Tento prŕstup může samosprávám nabídnout odpověd' na otázky, jak kulturu vhodně začlenit do jejich rozvojových politik jak využít znalosti a dovednosti místních aktérů a veřejnosti při plánování nebo jak zvýšit transparentnost pravidel podpory kultury. ${ }^{1}$

V textu nejprve vymezíme pojem kultura, a to zvláště s ohledem na pojetí blízké konceptům kulturního plánování a udržitelného a městského rozvoje. Dále se zabýváme principy kulturního plánování a začleňujeme tento přístup do aktuálního rámce a terminologie české veřejné politiky, na závěr přestavujeme doporučení pro jeho implementaci. Vycházíme

1 Rozpočty obcí, měst a krajů se významně podílejí na financování kultury. V souhrnu vydávají samosprávy na oblast kultury několikanásobně více finančních zdrojů, než ústř̌ední vládní instituce $(3,4$ krát v roce 2012, ČSÚ, NIPOS 2014). 
přitom $\mathrm{z}$ vlastní dvouleté zkušenosti s aplikací kulturního plánování v českém prostředí. $\mathrm{V}$ rámci akčního výzkumu připravil tým Sociologického ústavu AV ČR, v.v.i., metodiku², která byla využita při prŕípravě kulturního plánu, resp. koncepce ve dvou českých městech. Členové týmu poskytovali v rámci těchto procesů odbornou a metodickou podporu a zastávali roli konzultantů (více viz Vojtíšková - Poláková - Patočková 2016).

\section{JAK DEFINOVAT KULTURU}

Předpokladem úspěšné kulturní politiky je identifikace toho, co je kultura, k čemu je kultura využívána a jakých strategických cílů lze jejím prostřednictvím dosáhnout (Stevenson Rowe - McKay 2010, 250). Pojem „kultura“ je ve společenských vědách považován za jeden z nejpoužívanějších pojmů, kterému však zároveň chybí jednoznačnost; podle Raymonda Williamse (1983) jde o jedno ze dvou či tří nejsložitějších slov. Tento mnohdy až nadužívaný termín je součástí každodenního života a škála významů tomu odpovídá. Můžeme se setkat $\mathrm{s}$ celou řadou definic, typologií a různých přístupů $\mathrm{k}$ tomuto pojmu (srovnej Kroeber - Kluckhohn 1952; Eagleton 2001; Jenks 2005; Horáková 2012).

Kultura bývá někdy ztotožňována s uměním, estetikou a kultivací. S tímto tzv. úzkým pojetím kultury je spjatý hodnotící prvek. Kultura je vnímána jako prostředek k získávání pozitivních a společensky oceňovaných zážitků, jako jsou návštěvy divadelních představení, muzejních expozic, galerií, historických památek. Člověk věnující se kultuře je považován za kultivovanějšího a vzdělanějšího; disponuje kulturním kapitálem (Bourdieu 1986). Takto pojatá kultura bývala doménou elitních vrstev obyvatel a teprve postupně $s$ rozšiřováním vzdělání a volného času se v populaci stala dostupnější (Patočková - Čermák - Vojtíšková 2012).

$\mathrm{V}$ protikladu k tomuto vymezení stojí široké antropologické pojetí kultury, které reprezentuje např́iklad definice kultury britského antropologa Edwarda Burnetta Tylora. Ten o kultuře hovoří jako o „způsobu života“, tedy rozsáhlém komplexu jevů, který zahrnuje víru, morálku, právo, umění, vědění, zvyky, tradice, jazyk, způsob výchovy a všechny ostatní schopnosti, které si člověk osvojil jako člen lidské společnosti (viz Tylor 1871). V daném smyslu se kultura může považovat za nadbiologickou podstatu člověka, která není geneticky přenositelná z jedné generace na druhou. Stává se negenetickou kolektivní pamětí lidstva (Soukup 2000, 2011).

Pražská kulturologická škola vychází z předpokladu, že kulturu je možné zkoumat na třech úrovních. Jednak $\mathrm{v}$ atributivním smyslu jako univerzálně lidský fenomén, dále v distributivním smyslu na úrovni jednotlivých sociokulturních systémů, které je možné identifikovat v čase a prostoru, a také

2 Metodika provádí uživatele všemi fázemi procesu tvorby koncepčního dokumentu, seznamuje také s jeho implementací a obsahuje řadu konkrétních nástrojů pro jednotlivé fáze procesu (viz Vojtíšková a kol. 2015). na úrovni jednotlivce s ohledem na mechanismy osvojování si kultury v procesu socializace a enkulturace (Soukup 2012). $\mathrm{V}$ tomto pohledu lze nahlížet na město jako na konkrétní sociokulturní systém.

Pro regionální a lokální kulturu a její rozvoj, vč. praktického uplatnění principů kulturního plánování, je v českém kontextu užitečné vymezení kultury navržené Alenou Mockovčiakovou. V tomto pojetí není za kulturu považována pouze umělecká činnost nebo její výsledky, ale „i poznávací, osvětové, zájmové a vzdělávací aktivity, stejně tak i spolková činnost, tradice a zvyky, dokonce i prŕrodní a urbanizované prostředí individuálního života“ (Mockovčiaková 2006, 1). Patři sem např́klad činnosti muzeí, galerií, památkových objektů, kin, divadel, knihoven, stejně jako nabídka společenských, kulturních a vzdělávacích programů, činnosti dobrovolnických občanských aktivit, nevládních neziskových organizací, ale i městské slavnosti a festivaly (Mockovčiaková 2006).

Klíčovým pojmem kulturního plánování je termín kulturní zdroje (Teaiwa - Mercer 2011, 14; Grogan - Mercer - Engwicht 1995, 13; Landry 2008; Mercer 2002, 173-5; Baeker 2010, 46-47; Kovacs 2011). Mezi kulturní zdroje bývají řazeny:

- Kulturní a kreativní průmysly/odvětví: architektura, design, reklama, film, fotografie, hudba, knihy a tisk, scénická umění, trh s uměním, TV a rozhlas, média, videohry, kulturní cestovní ruch, komerční galerie.

- Lidé různých kulturních povolání a zálib: architekti, spisovatelé, editoři, hudebníci, fotografové, designéři, herci, výtvarníci, básníci, učenci, kurátoři, historici.

- Kulturní zařízení a prostory: galerie, muzea, divadla, knihovny, kulturní domy, archivy, designová studia, mediální studia.

- Nehmotné statky: znalost příběhů, zvyků, písně, orální tradice, dialekt, obřady/slavnosti, pojmenování míst, způsoby vaření jídla, receptury.

- Kulturní dědictví: památkové objekty, významné budovy, hřbitovy, archeologická místa, historická místa, chráněné zóny.

- Přírodní dědictví: farmy a sady, parky, botanické/zoologické zahrady, ochranářské organizace, kulturní krajina, chráněná území.

- Kulturní události a festivaly: filmové, multikulturní festivaly, festivaly divadelní, literární, hudební, muzejní noci, noci kostelů, výlety za uměním a kulturním dědictvím, taneční vystoupení.

- Umělecké sítě, výstavy, setkání.

- Komunitní organizace a jejich sítě: multikulturní organizace, historické a genealogické společnosti, místní umělecká sdružení, církevní spolky, Sokol.

\section{KULTURA A UDRŽITELNÝ ROZVOJ}

Hlavní zásady konceptu trvale udržitelného rozvoje byly vymezeny již v roce 1987 ve zprávě připravené týmem vedeným bývalou norskou premiérkou Gro Harlem Brundtland s ná- 
zvem Naše společná budoucnost. V roce 1992 došlo v Rio de Janeiro k přijetí akčního plánu Agenda 21 (OSN 1992), který představoval nástroj systematického směřování $\mathrm{k}$ udržitelnému rozvoji a na místní úrovni se rozšíril pod názvem Local Agenda 21, v České republice jako Místní agenda 21 (MA 21). Diskurz se věnoval hlavně vztahům mezi ekonomickou, sociální a environmentální dimenzí a kulturu do značné míry opomíjel.

$\mathrm{Na}$ tento nedostatek reaguje Agenda 21 pro kulturu (Agenda 21 for culture), iniciativa výboru pro kulturu při organizaci $\mathrm{UCLG}^{3}$, která od roku 2004 upozorňuje na nedoceněný význam kultury pro lidský rozvoj a koncept udržitelnosti, potřebu strategického využívání kulturních zdrojů při správě měst a obcí a stanovení dlouhodobé vize kultury v rozvojových strategiích. Implementace Agendy 21 pro kulturu v konkrétním území může být chápána jako př́ílad aplikace procesu kulturního plánování (viz UCLG 2006).

Agenda 21 pro kulturu prosazuje, aby kultura zaujímala rovnocenné místo mezi tradičními "pilíři“ udržitelnosti - environmentálním, sociálním a ekonomickým (UCLG 2004; 2010) nebo aby byla zařazena mezi hlavní cíle agendy OSN po roce 2015. Kultura je definována ve smyslu kultury blízce vázané na místní společenství a každodenní život (viz např. Hawkes 2001; Duxbury, Gillette 2007). Dosavadním vrcholem těchto snah byl první kulturní summit Culture and Sustainable Cities pořádaný v březnu 2015 v Bilbau, na kterém delegáti přijali nový programový dokument s názvem Culture 21: Actions (UCLG 2015).

Čtyřpilírový princip udržitelného rozvoje již přijala Kanada (Baeker 2010, 32) a na nejvyšší úrovni je kultura stále více uznávána jako důležitá dimenze udržitelného rozvoje (např. OSN 2013). V České republice je odezva na propojování kultury a udržitelného rozvoje zatím poměrně slabá, což se projevuje v praxi ve složení Rady pro udržitelný rozvoj, ve které chybí zástupce Ministerstva kultury ${ }^{4}$, nebo v indikátorech Strategického rámce udržitelného rozvoje ČR (MŽP 2010), kde se kultury týká jediný ze 48.

\section{KULTURA A MĚSTSKÝ ROZVOJ - OD KULTURNÍ POLITIKY KE KULTURNÍMU PLÁNOVÁNÍ}

Kultura (byt' různě definovaná) je odborníky a stále více i praktiky chápána jako důležitý zdroj (místního a městského) rozvoje. Kultura není jen „třešničkou na dortu“ či "nadstavbou”, stává se uznávanou sama o sobě, jako kapitál, často v úzkém spojení s kreativitou. Tradiční kulturní politiky, které vycházejí z estetické definice kultury („vysoké uměni“) a z oborového členění kultury, jsou vnímány jako překonané.

Do centra pozornosti odborníků zabývajících se rozvojem

3 United Cities and Local Governments, česky Spojená města a místní samosprávy.

4 Stav po renominaci členů Rady na podzim 2014 (viz http://www. vlada.cz/cz/ppov/rada-vlady-pro-udrzitelny-rozvoj--120432/). měst se kultura pod značkou kulturou taženého rozvoje (cultural-led development) dostala v posledních desetiletích $\mathrm{v}$ souvislosti s hlubokými a komplexními změnami, kterými města procházela zejména $\mathrm{v}$ návaznosti na transformační změny, deindustrializaci, (sub)urbanizaci, vzestup technologií. Objevují se nové pojmy jako kreativní město (creative city) Charlese Landryho (2008) nebo kreativní třída (creative class) Richarda Floridy (2003). V odborné literatuře se setkáme s mnoha přístupy kulturního plánování, ovšem je třeba uvést, že mohou být vzájemně kontradiktorní, např́íklad politicky, epistemologicky, definičně (viz např. Grodach - Loukaitou-Sideris 2007; Evans 2013; Evans - Foord 2008). Za úspěšné jsou považovány projekty zaměřené na kulturu, které pomohly přilákat vnější investice a kvalifikované pracovníky, přispěly $\mathrm{k}$ regeneraci zanedbaných míst, $\mathrm{k}$ rozvoji turismu a povzbudily hrdost jeho obyvatel (García 2004; v českém kontextu Marková - Slach 2013). Bilbao, Toronto či Glasgow jsou příklady měst, která „vsadila“ na kulturu a investovala do vzniku kulturních čtvrtí, kulturních zařízení, podpory kreativních průmyslů/odvětví či velkých akcí, jako je prestižní titul Evropské hlavní město kultury (Vojtíšková 2015).

Někteří autoři však kriticky upozorňují na odvrácenou stranu, která spektakulární projekty regenerace často doprovází - rostoucí sociální nerovnosti, gentrifikaci a vymístování (displacement) určitých obyvatel a nedostatek podpory nezávislých a nekomerčních uměleckých iniciativ. Kromě toho poukazují i na potřebu empiricky zkoumat strategie měst vzhledem $\mathrm{k}$ reálným př́nosům a udržitelnosti (např. Miles 2005; Markusen - Gadwa 2010).

Sociálně nepříznivých důsledků, které může vyvolávat politika rozvoje založeného na kultuře, se snaží vyvarovat kulturní plánování, které představuje kulturně citlivý participativní proces $\mathrm{v}$ rámci lokálního a regionálního plánování (Bianchini 2013), vycházející z místních potřeb a specifik a postavený na široce definovaných kulturních zdrojích. Tím se odlišuje od sektorově orientovaných uzavřených tradičních kulturních politik. Podrobněji je rozdíl mezi kulturní politikou a kulturním plánováním zachycen $\mathrm{v}$ Tabulce 1 .

Za předchůdce kulturního plánování bývá považován skotský zakladatel městského a regionálního plánování Patrick Geddes, který na počátku 20. století mezi principy plánování prosazoval rozpoznání toho, jak se utvářejí vazby mezi kulturou a místem, prací a lidmi (place, work, folk). Podle Geddese „urbanisté potřebují být - nebo by měli být - informováni antropology, ekonomy a geografy a nikoli jen techniky a projektanty. Potřebují vědět, jak lidé žijí, pracují, baví se a jak se vztahují ke svému okolí“ (podle Bianchini 2013, 379; Mercer 2002, 171).

Kulturní plánování se široce využívá v USA již od 70. let a v Austrálii od poloviny 80. let. 20. století (Grogan - Mercer - Enwicht 1995; Stevenson 2005). Jeho cílem bylo hlavně rozvinout městskou kulturní infrastrukturu jako způsob podpory místních komunit, občanství a ekonomiky (Stevenson 2004, 2005).

Zatímco podle Lii Ghilardi bylo v Evropě kulturní plánování 


\begin{tabular}{|l|l|l|}
\hline & \multicolumn{1}{|c|}{ KULTURNí POLITIKA } & \multicolumn{1}{c|}{ KULTURNÍ PLÁNOVÁNÍ } \\
\hline Definice kultury & $\begin{array}{l}\text { Estetická - zejména „vysoké umění } \\
\text { a kulturní průmysly }\end{array}$ & $\begin{array}{l}\text { Kulturní zdroje - širší pohled na místní } \\
\text { kulturní kapitál a zdroje }\end{array}$ \\
\hline Základní perspektiva & $\begin{array}{l}\text { Oborové členění - disciplinární, } \\
\text { např. divadlo, muzea, tanec apod. }\end{array}$ & $\begin{array}{l}\text { Teritoriální členění - zaměření } \\
\text { na celostní perspektivu danou místem }\end{array}$ \\
\hline $\begin{array}{l}\text { Podnět pro intervenci ze } \\
\text { strany vedení/vlády }\end{array}$ & $\begin{array}{l}\text { Vnitřní hodnota umění, ekonomické } \\
\text { dopady }\end{array}$ & $\begin{array}{l}\text { Důraz na př́nosy pro městský rozvoj } \\
\text { (široce definovaný) }\end{array}$ \\
\hline Role vlády/vedení & Př́stup shora & Př́stup zdola \\
\hline $\begin{array}{l}\text { Kdo určuje umělecké nebo } \\
\text { kulturní hodnoty }\end{array}$ & $\begin{array}{l}\text { Umělečtí producenti a instituce, autority } \\
\text { oborů }\end{array}$ & $\begin{array}{l}\text { Vyjednávání o hodnotách probíhá mezi } \\
\text { uměním a publikem či komunitou }\end{array}$ \\
\hline Hlavní účastníci & $\begin{array}{l}\text { Komunita profesionálů v umění, } \\
\text { kulturním dědictví, kulturních } \\
\text { průmyslech }\end{array}$ & $\begin{array}{l}\text { Kulturní sektor, zástupci místních obyvatel, } \\
\text { zástupci komunitních organizací, místních } \\
\text { podnikatelù apod. }\end{array}$ \\
\hline Chápání kulturního rozvoje & $\begin{array}{l}\text { Kulturní rozvoj jako rozvoj kulturního } \\
\text { sektoru. Zacílení na zvyšování kvality, } \\
\text { intenzity a dopadu }\end{array}$ & $\begin{array}{l}\text { Kulturní rozvoj vnímán jako porozumění } \\
\text { kultuře jako zdroji rozvoje člověka. Širší cíle } \\
\text { v sociální oblasti }\end{array}$ \\
\hline
\end{tabular}

Tab. 1: Srovnání kulturní politiky s kulturním plánováním. Zdroj: vlastní zpracování podle Baeker 2002.

na přelomu tisíciletí ještě skoro neznámé (Ghilardi 2001), Deborah Stevenson datuje jeho začátky ve Velké Británii již do 80. let a spojuje je s vlivem Labour Party (Stevenson 2004). K rozvoji kulturního plánování přispěl úspěch skotského města Glasgow jako Evropského hlavního města kultury v roce 1990, a také několika dalších, dříve průmyslových měst (Liverpool apod.). Nyní se od britských samospráv očekává, že vypracovávají kulturní strategie.

Po roce 2000 došlo $k$ rozšíření kulturního plánování v Evropě (např. Rakousko - Linz, Německo - obce a regiony Vestfálska). Zejména po roce 2005 se rozšiřruje kulturní plánování v Kanadě (Baeker 2010; Kovacs 2010, 2011).

Obecně lze říci, že kulturní plánování je prríležitostí, jak do veřejné politiky týkající se širokého spektra občanských témat přinést otevřenější a kreativní praktiky (Ghilardi 2001). Kulturní plánování může být přínosné pro řadu oblastí života ve městě: ekonomiku, turismus, sociální a komunitní rozvoj (sociální kapitál), integrované plánování území (Grogan - Mercer - Engwicht 1995). Na základě české zkušenosti bychom zmínili př́nosy vedoucí ke zvýšení dostupnosti kultury nebo rozšíření možností kulturního a uměleckého vzdělávání.

Ekonomické př́nosy kultury jsou spojeny s kulturními a kreativními odvětvími nebo rozvojem menšího a středního podnikání vázaného na turismus nebo kulturní akce. Rozvoj kultury znamená zájem o kvalitu života obyvatel, mezilidských vztahů ve městě, posilování společenství - komunity (sociální soudržnost) a místní identity - patriotismu (kulturní udržitelnost). Specifické projevy kultury a atmosféra je tím, co $\mathrm{v}$ globalizovaném světě činí $\mathrm{z}$ města/místa vedle prŕijemného místa $\mathrm{k}$ životu také atraktivní destinaci.
Kulturní plánování podporuje participaci veřejnosti na plánování s předpokladem, že lidský potenciál („lidské zdroje”) je jedním z nejdůležitějších faktorů pro sociální kohezi, kvalitu života a tvorbu bohatství (Landry 2008).

\section{PROCES KULTURNÍHO PLÁNOVÁNÍ - HLAVNÍ PŘEDPOKLADY, PRINCIPY A PŘÍNOSY}

Kulturní plánování se skládá $\mathrm{z}$ několika základních fází. Výstupem plánovacích procesů bývá většinou strategický či koncepční dokument, přijatý radou nebo zastupitelstvem města. Může být samostatným dokumentem, ale vždy navázaným na strategii městského a regionálního rozvoje (pokud město/kraj takovým dokumentem disponuje), respektive integrovaný do ostatních plánovacích procesů $\mathrm{v}$ rámci města. Neoddělitelnou součástí kulturního plánování je kulturní mapování, které poskytuje určitou výpověd' o stavu „kulturního bohatství na daném území, dochází při něm k identifikaci místních kulturních zdrojủ (Cultural Resource Mapping ... 2010, Stewart 2010, Rowe 2012). Pracuje se tak se znalostmi o jedinečnosti prostředí a charakteristikách místních komunit a obyvatel, které spoluovlivňují kulturní poptávku a nabídku daného místa.

Proces kulturního plánování lze rozdělit do čtyř základních fází:

1. Př́pravná fáze (získání široké podpory procesu ze strany politické reprezentace a veřejnosti, př́prava organizačních struktur, identifikace a zapojení klíčových aktérů), 


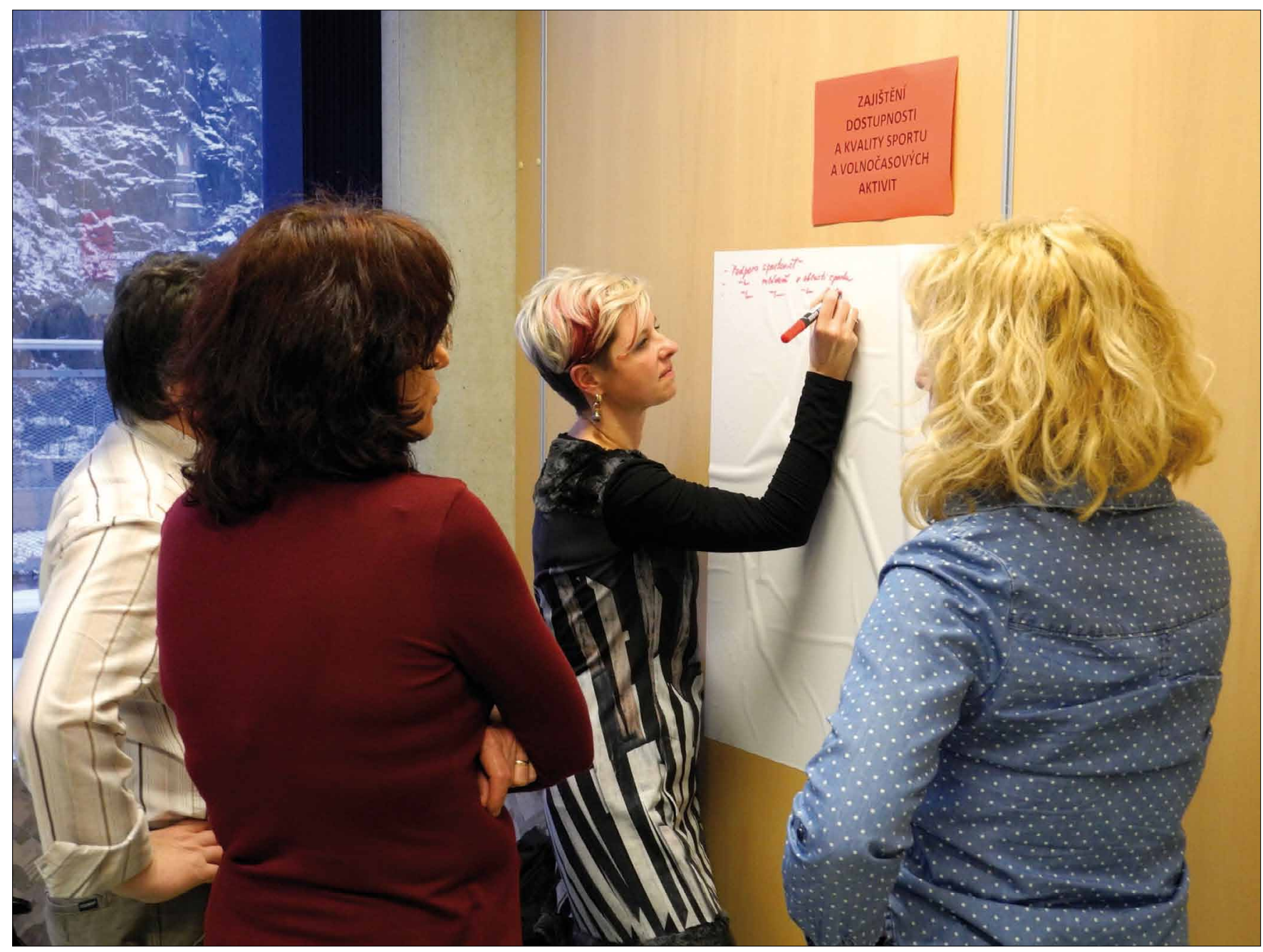

Obr. 1. Kulturní plánování v Děčíně. Zdroj: autorská forografie.

2. Kulturní mapování (výzkum, poznávání, př́íprava analytických podkladů pro dokument),

3. Vytváření a schvalování dokumentu (práce založená na vytvořené platformě otevřené pracovní skupiny a menších tematicky zaměřených týmech, informování politické reprezentace a veřejnosti),

4. Implementace dokumentu (převedení kulturního plánu do praxe, hodnocení úspěšnosti).

Rozvíjení participativních a komunitních př́stupů, které spočívají v zahrnutí širokého spektra aktérů pro řešení společných cílů a hledání průniků mezi jejich zájmy, se považuje za jednu z cest oživování demokracie (Khendriche Trhlínová 2014) a budování (kolektivního) sociálního kapitálu, sítí sociální podpory, reciprocity a důvěry (Putnam 2000; Sedláčková 2012). Z výzkumů vyplývá, že v České republice stále není občanská participace dostatečně rozvinuta. Hlavními důvody jsou nezájem, odcizení lidí od politiky a politiků, míra nedůvěry nebo přisuzování malého vlivu občanů na rozhodování o důležitých otázkách (viz např. Čermák - Vobecká a kol. 2011).
Proces kulturního plánování také prakticky usnadňuje propojování (aktérů z) různých oborů, sektorů a oblastí, které spojuje zájem o dané místo - lokalitu (teritoriální přístup). Je tak vhodný pro provázání kultury s cestovním ruchem, se sportem, se vzděláváním nebo urbanismem. Postavení jednotlivých sektorů by mělo být rovnoprávné, kultura by tedy neměla být naprríklad podřízena cestovnímu ruchu.

Svou roli v procesu mají také nejrůznější odborníci/experti, a to především ve fázi kulturního mapování, kde je vhodné aplikovat různé metody a techniky k oslovení veřejnosti, analýze dat a statistik a vytváření mapových podkladů apod. Odborníky lze využít také k facilitaci - profesionálnímu a nestrannému vedení setkání, které nastoluje atmosféru spolupráce a otevřené komunikace a důvěry.

V České republice může propojení slov kultura a plánování v návaznosti na dobu před rokem 1989 vyvolat určité pochybnosti a otázky. Tou zřejmě nejzásadnější je, jestli je možné kulturu plánovat a zda proces neohrozí uměleckou svobodu a nepotlačí kreativitu lidí - místních komunit. Zda se výsledný koncepční dokument či „plán“ nestane 


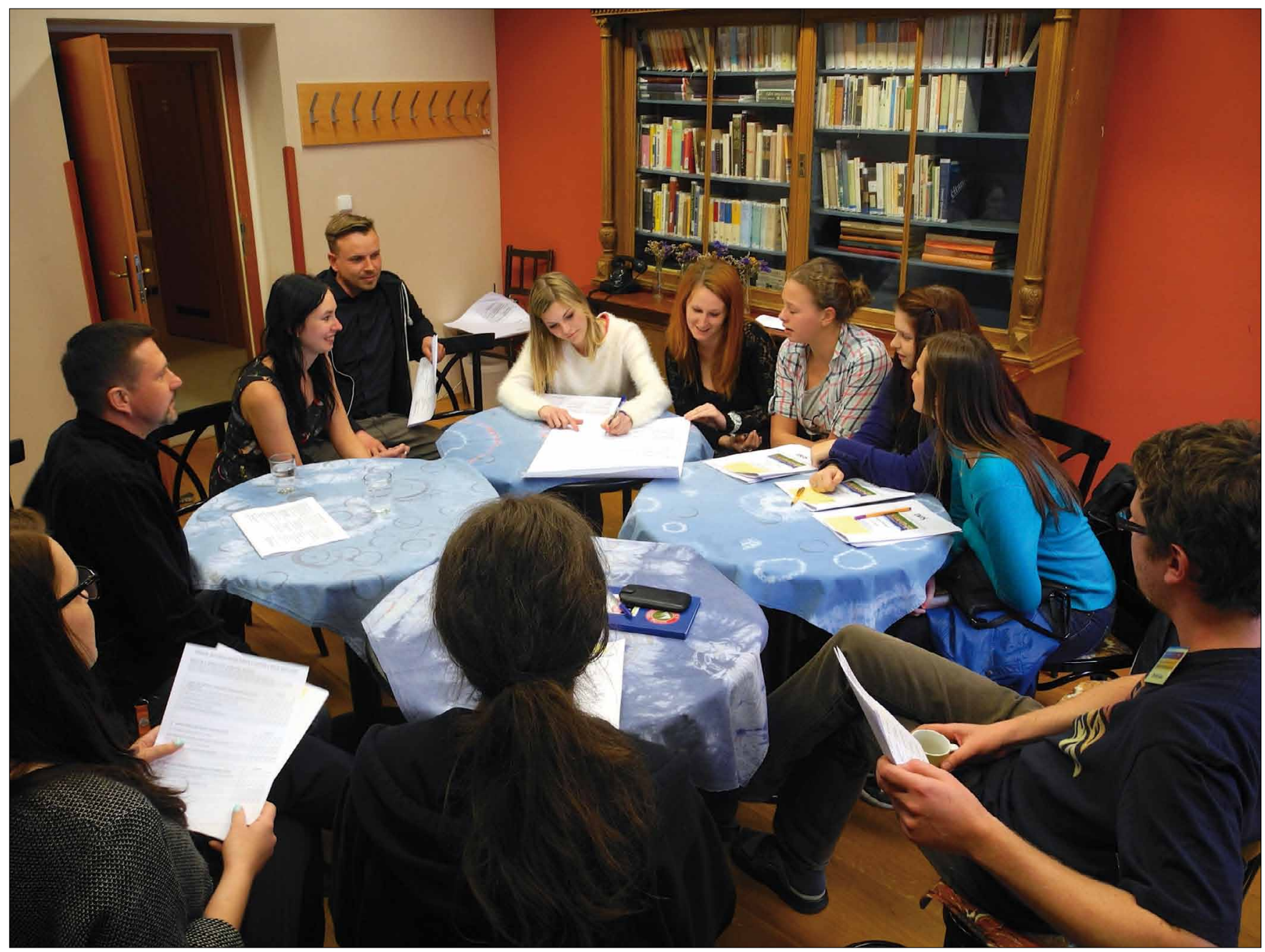

Obr. 2. Mapování kulturních zdrojů za účasti obyvatel v Lounech. Zdroj: autorská forografie.

překážkou pro spontánní aktivity a neohrozí realizaci předem nenaplánovaných akcí. Takové důsledky by ale byly $\mathrm{v}$ př́mém rozporu $\mathrm{s}$ cíli kulturního plánování, které nemá spočívat v direktivním „naplánováni“ kultury a formálním plnění plánů. $V$ kulturním plánování jde především o snahu lépe porozumět unikátnosti města/místa, zdůraznit a uznat význam kultury a reagovat na současné prríležitosti měst i na problémy, kterým jejich obyvatelé čelí.

Colin Mercer (2002) nicméně vhodně upozorňuje, že bychom si měli být vědomi toho, že západní kultura byla vždy svým způsobem plánována a řízena, především skrze vzdělávací systém a další instituce či politiky. Kulturní plánování má být tvůrčí a dynamický proces, který aktérům umožňuje reagovat na měnící se situaci a nové potřeby, dává dostatek prostoru pro rozvoj tvưrčího myšlení. Př́ilišný formalismus nebo direktivní usměrňování by tlumilo chut aktérů se zapojit. Je tedy nutné hledat rovnováhu mezi na jedné straně transparentností a zachováním procedur, a na druhé straně flexibilitou a kreativitou $\mathrm{v}$ procesu.

\section{KULTURA A KULTURNÍ PLÁNOVÁNÍ V KONTEXTU ČESKÉ VEŘEJNÉ POLITIKY}

$\mathrm{Z}$ české legislativy je pro kulturní plánování podstatný především zákon o obcích (128/2000 Sb.), který obcím garantuje autonomii při výkonu samosprávy a zároveň stanovuje, že obec má pečovat o uspokojování potřeb svých občanů, včetně potřeby celkového kulturního rozvoje. Zákon zmocňuje orgány samosprávy rozhodovat o poskytnutí finančních prostředků fyzickým a právnickým osobám na podporu kultury ( $\$ 85$ cit. zák.). Kultura patří dále mezi vybrané oblasti podpory dle zákona o podpoře regionálního rozvoje ( $\$ 3$ zákona $248 / 2000$ Sb.).

$\mathrm{Na}$ všech úrovních veřejné správy se ukazuje potřeba předvídatelného prostředí, transparentních, objektivních a nediskriminačních pravidel, spolupráce napříc úrovněmi veřejné správy nebo využití kreativity při různých lidských aktivitách. Rétorika českých koncepčních dokumentů vypovídá o kultuře jako o významném faktoru (regionálního) rozvoje (MMR 
2006), jako o základní součásti společnosti založené na znalostech (MŽP 2004), „jízdence do budoucnosti“ nebo integračním prvku společnosti (MK 2009). Dokumenty se zabývají i přesahy a propojováním kultury do ostatních sektorů a oblastí společnosti (MK 2009), kultura se například považuje za výrazný a stále nedostatečně využitý potenciál pro cestovní ruch (MMR 2013b).

Potenciál kultury pro místní rozvoj je spojován zejména $s$ kulturním dědictvím a obecně kulturními hodnotami, které přispívají ke zvýšení atraktivity destinací pro návštěvníky (viz Tittlebachová 2011; MMR 2013a). V dokumentech se často prolínají důrazy na ekonomickou i sociální funkci kultury. Městům se doporučuje, aby vytvářela „kulturní politiku a podmínky pro rozvoj kulturních a jiných aktivit pro využívání volného času" (MMR 2010, 38). Kraje a obce mají ve větší míre uplatňovat strategické a participativní prístupy a umožnit veřejnosti účast na rozhodování a tvorbě strategií (MŽP 2004). Samosprávám je doporučeno povzbuzovat iniciativu obyvatel, rozvíjet spolupráci a partnerství mezi relevantními aktéry (např. svazky obcí, místními akčními skupinami, kulturními institucemi, subjekty podnikatelské a neziskové sféry), zvyšovat kvalitu volnočasových aktivit a rozšiřovat nabídku sportovního a kulturního vyžití (včetně neformálních aktivit).

Dokumenty také varují před podceňováním ekonomického významu kultury a pokračujícím chápáním kultury ,jen jako čistě spotřebovávajícího odvětví a nikoli jako faktoru rozvoje lidského potenciálu“" (MŽP 2004, 23).

Sociální př́ínosy kultury se vztahují ke kultuře jako mediátoru hodnot, sociálních kompetencí, zdravého životního stylu - kultura přispívá $\mathrm{k}$ sebedůvěře, sebepoznání, rozvoji osobnosti, identity (MK 2009), sounáležitosti lidí s obcí, regionem i státem, vzdělávání a $\mathrm{k}$ náplni volného času. Ve svém důsledku tak může napomoci prevenci před kriminalitou či sociálně nežádoucími jevy, být prostředkem v úsilí o sociální začleňování znevýhodněných skupin a minorit či stimulaci interkulturního dialogu (MŽP 2010). Některé dokumenty cílí na vybrané, sociálně znevýhodněné kategorie obyvatel jako je mládež (smysluplná volnočasová náplň), senioři (diskurz aktivního stárnutí), minority nebo handicapovaní.

Státní kulturni politika reflektuje mezinárodní diskurz (zejména UNESCO, EU), který se sice pohybuje na obecné úrovni, ale poskytuje rámce podpory aktivní tvořivé spoluúčasti veřejnosti na kulturním životě (MK 2009). Dokument explicitně zdůrazňuje „prosazování participačních politik a opatření, které zahrnují požadavky zachování dědictví a zároveň i rozvojové požadavky a přispívají $\mathrm{k}$ sociální soudržnosti a inovacím“" (MK 2009, 60).

Dokument Zásady urbánní politiky je pozoruhodný $\mathrm{v}$ tom, že kulturu explicitně řadí mezi pilirire udržitelného rozvoje: „Ekonomický, environmentální, sociální a kulturní piliř udržitelného rozvoje dnes již nelze chápat odděleně a vytvářet izolované podpory jednotlivým oblastem" (MMR 2010, 48). Zvláštní důraz klade na ochranu kulturního a př́rodního dèdictví s ohledem na potenciálně ničivé dopady globalizace. Lze shrnout, že prístup kulturního plánování je v souladu s obecnějšími zásadami české veřejné politiky a s ustanovení- mi, která jsou uvedena v mezinárodních dokumentech týkajících se kultury. Ke snazší aplikaci kulturního plánování může přispět, že některé dokumenty ke kultuře prristupují ve smyslu definice Aleny Mockovčiakové (viz výše).

\section{ZKUŠENOSTI Z KULTURNÍHO PLÁNOVÁNÍ V ČESKÉ REPUBLICE}

Kulturní plánování ve smyslu prezentovaném v textu je v České republice dosud ojedinělé. Koncepční dokumenty, které by zdůrazňovaly širší význam kultury, vznikají v České republice zatím spíše v největších městech (Praha, Plzeň, Ostrava, Brno) a spíše nahodile se diskuse rozšiřují do menších měst a sídel. Např́ílad projekt „Mapování pardubické kultury“ přistupoval ke kultuře jako ke zdroji kreativity ve společnosti, kreativní ekonomiky a konkurenceschopnosti měst s cílem získat podklady pro strategické uvažování o tom, „co kultura a umění v Pardubicích potřebují, aby mohly být živým podhoubím města" (viz http://www.pardubickepodhoubi.cz).

Příkladem menších měst, kde bylo aplikováno kulturní plánování, jsou města Děčín a Louny, která prošla (v letech 2013 2014) prvními třemi kroky kulturního plánování od úvodních jednání, mapování kulturních zdrojů, přes tvorbu dokumentu se zapojením místních aktérů až po projednání dokumentu městskými radami. $\mathrm{V}$ případě Děčína Kulturní plán schválilo zastupitelstvo města. Tyto procesy byly realizovány podle metodiky vypracované týmem, jehož byly autorky tohoto článku součástí. Zkušenosti autorek z aplikace kulturního plánování $\mathrm{v}$ těchto městech, na které se $\mathrm{v}$ letech 2013 a 2014 podílely, umožňují konfrontovat jeho principy i zahraniční aplikace s českou praxí (Vojtíšková - Poláková - Patočková 2016).

$\mathrm{Na}$ základě poznatků získaných $\mathrm{v}$ terénu lze konstatovat, že kultura stále není v praxi českých měst vnímána jako přirozená a významná součást individuálního i společenského života a naopak je její role spiše zužována na péči o kulturní památky, provoz městských př́spěvkových organizací, případně organizaci městských slavností. Podcenění kultury $\mathrm{v}$ životě města je patrné i $\mathrm{z}$ absence nebo poddimenzování počtu samostatných pracovníků, kteří by měli na starosti kulturu na městských úřadech/magistrátech. Podpora rozvoje kultury na místní úrovni se pak někdy omezuje na diskusi o výši a způsobech rozdělení veřejných prostředků $\mathrm{v}$ rámci městských/regionálních dotačních titulů. Často chybí diskuse o významu kultury v životě města (vzhled města, vzdělávání, trávení volného času, ekonomická situace atd.).

Členové řešitelského týmu se $\mathrm{v}$ terénu opakovaně setkávali $s$ potřebou prrekonat bariéry převládajícího úzce resortního pohledu a odtrženost oblasti kultury od dalších oblastí, obzvláště cestovního ruchu, sportu a vzdělávání. Problémy se vyskytují i v rámci systému veřejné správy. Mezisektorový (mezioborový, resp. meziodborový) pracovní tým $\mathrm{v}$ rámci úrúadu může usnadnit komunikaci pracovníků působících v různých odděleních či odborech, kteří dříve $\mathrm{v}$ kontaktu nebyli. Jednou z možností, jak funkčně propojit oblast cestovního ruchu s kulturou, je využití Městského informačního centra, kte- 


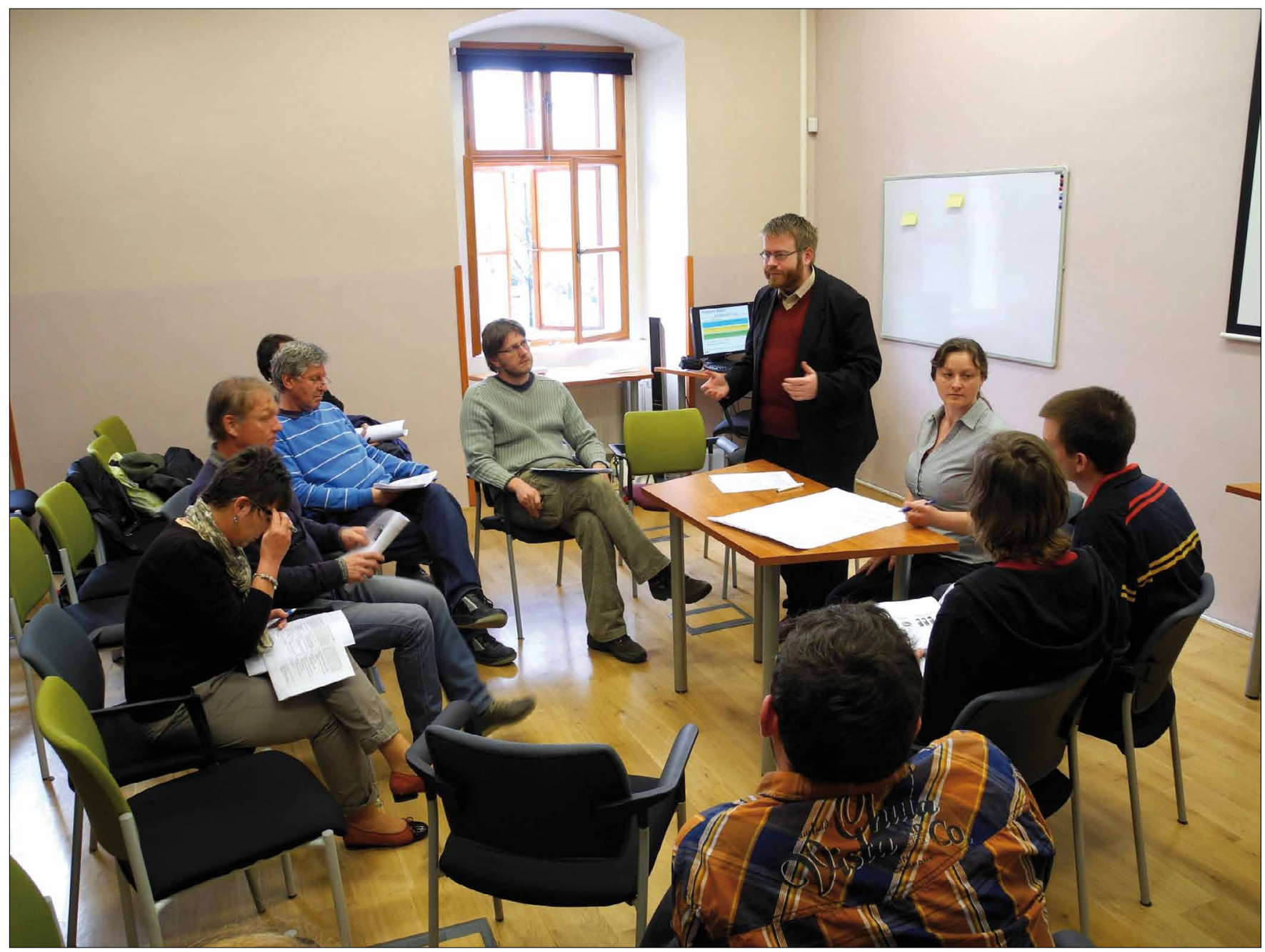

Obr. 3. Veřejné projednávání dokumentu v Lounech. Zdroj: autorská forografie.

ré vedle své orientace na návštěvníky komunikuje i s širokou skupinou místních kulturních aktérů a lokální komunitou. Problémy vyplývající $\mathrm{z}$ nedostatečné koordinace a kooperace mezi aktéry jsou $\mathrm{v}$ českém prostředí poměrně časté. $\mathrm{V}$ jejich důsledku dochází ke zdvojování a překryvům agend, resp. nepokrytí určitých hraničních oblastí, k nejasnému vymezení kompetencí, k nepřesnosti v komunikaci uvnitř i navenek a $\mathrm{k}$ řadě dalších nedorozumění.

Kulturní plánování poskytuje oporu pro udržení stávajících a vytváření nových partnerství aktérů napříč sektory (veřejný, neziskový, soukromý sektor) a úrovněmi veřejné správy, například formou méně formálních komunikačních platforem. Lepší komunikace, koordinace a spolupráce může pomoci např́íklad při přípravě projektových žádostí a čerpání dotací. Kulturní plánování je založeno na inkluzivním přístupu, umožňuje všem, kteří se o dané téma zajímají, aby se zapojili do procesu plánování. Může však trvat i několik let, než se daný způsob komunikace uvnitř komunity „zažije“.

Předpokladem úspěšnosti procesu je dostatek relevantních a kvalitních dat a analýz. Na místní úrovni je přitom patrná absence potřebných dat i vědomí, že jsou pro rozhodování a plánování (nejen v kulturní oblasti) nezbytná. K podcenění odbornosti dochází také při aplikaci participačních metod a komunikace s občany. Angažování nestranných facilitátorů pomáhá odstranit zábrany $\mathrm{k}$ diskusi o obtížných a někdy i kontroverzních tématech. Osobní zkušenosti ukázaly, že je vhodné kombinovat expertní a komunitní přístupy a že by proces měl probíhat transparentně podle předem daných pravidel, srozumitelných všem aktérům. Pro úspěšnou implementaci kulturního plánování je rovněž nezbytná politická podpora a zájem vedení města.

\section{ZÁVĚR}

Kulturní plánování, které vychází z širšího pojetí kultury, se nabízí jako vhodný nástroj proměny plánovací praxe na lokální a regionální úrovni. Tento potenciál však nebyl (až na výjimky) doposud místními samosprávami v České republice účinně a systematicky využit a pochopen v celé šíri a návaz- 
nostech. K dosažení zásadnější změny je nezbytné realizovat sérii postupných kroků, které povedou k proměně praxe úřadů a jednotlivých organizací, větší otevřenosti vůči novým výzvám a nárokům, schopnosti reagovat na aktuální jevy a vzájemně se učit.

Komunikační platforma vycházející z aplikace kulturního plánování může pomoci předcházet problémům v koordinaci aktivit na daném území, podpořit participaci různých místních aktérů a přispět $\mathrm{k}$ vytvoření stabilněǰ̌́ho a předvídatelnějšího prostředí (nastavení pravidel) příznivého pro rozvoj kultury. Takové prostředí by nemělo být definováno $\mathrm{v}$ přímé závislosti na stávající politické reprezentaci, ale spíše „,apoliticky“ tak, aby vycházelo z potřeb a aspirací místních lidí. Již samotná př́íprava dokumentu může pomoci $\mathrm{k}$ lepšímu provázání aktérů, utvoření nových kontaktů a rozvoji komunikace a spolupráce $\mathrm{v}$ daném území. Na druhou stranu je třeba realisticky zvažovat cíle procesu a podmínky jeho udržitelnosti a nevytvářet iluzi, že kultura mủže být všelékem na společenské problémy.

Otázkou zůstává, do jaké míry lze ambiciózní principy kulturního plánování vtělit do běžné plánovací praxe a práce v rámci úř́adů a samospráv, pokud se jim nedostane systematické podpory nejen na lokální, ale také na národní nebo regionální úrovni.

\section{LITERATURA}

Baeker, G. (2002): Beyond Garrets and Silos. Concepts, Trends and Developments in Cultural Planning. (online). http://uwsculturalplanning.files. wordpress.com/2013/09/baeker-report-on-cultural-planning.pdf.

Baeker, G. (2010): Rediscovering the wealth of places. A municipal cultural Planning handbook for Canadian communities. St. Thomas: Municipal World Inc.

Bianchini, F. (2013): Cultural Planning and Its Interpretations. In: Young, G. - Stevenson, D., eds., The Ashgate Research Companion to Planning and Culture. Surrey, Burlington, VT: Ashgate Publishing Ltd., 377-391.

Bourdieu, P. (1986): The forms of capital. In: Richardson, J. G., ed., Handbook of Theory and Research for the Sociology of Education. New York: Greenwood, 241-258.

Cultural Resource Mapping: A Guide for Municipalities (2010). (online). http://www.ontariomcp.ca/toolkits/CulturalResourceMapping_digital. pdf.

Čermák D. - Vobecká, J. a kol. (2011): Spolupráce, partnerství a participace $v$ místní veřejné správě: význam, praxe, př́slib. Praha: Sociologické nakladatelství (SLON).

ČSÚ, NIPOS. (2014): Výsledky účtu kultury ČR za rok 2012. Praha: Český statistický úrad, Národní informační a poradenské středisko pro kulturu.

Duxbury, N. - Gillette, E. (2007): Culture as a key dimension of sustainability: Exploring concepts, themes, and models. Vancouver: Simon Fraser University.

Eagleton, T. (2001): Idea kultury. Brno: Host.

Evans, G. (2013): Cultural Planning and Sustainable Development. In: Young, G. - Stevenson, D., eds., The Ashgate Research Companion to Planning and Culture. Surrey, Burlington, VT: Ashgate Publishing Ltd., 223-238.

Evans, G. - Foord, J. (2008): Cultural mapping and sustainable communities: planning for the arts revisited. Cultural trends, 17(2), 65-96.

Florida, R. (2003): Cities and Creative Class. City \& Community, 2(1), 3-19.

García, B. (2004): Cultural Policy and Urban Regeneration in Western European Cities: Lessons from Experience, Prospects for the Future. Local Economy, 19(4), 312-326.
Ghilardi, L. (2001): Cultural Planning and Cultural Diversity. In: Bennett, T., ed., Differing Diversities: Cultural Policy and Cultural Diversity. Strasbourg: Council of Europe Publishing, 123-134.

Grodach, C. - Loukaitou-Sideris, A. (2007): Cultural development strategies and urban revitalization. International Journal of Cultural Policy, 13(4), 349-370.

Grogan, D. - Mercer, C. - Engwicht, D. (1995): The Cultural Planning Handbook. An essential Australian guide. St Leonards: Allen \& Unwin.

Hawkes, J. (2001): The fourth pillar of sustainability. Culture's essential role in public planning. Melbourne: The Cultural Development Network.

Horáková, H. (2012): Kultura jako všelék? Kritika soudobých přistupů. Praha: Sociologické nakladatelství (SLON).

Jenks, C. (2005): Culture. London, New York: Routledge.

Khendriche Trhlínová, Z. (2014): Partnerství v rozvoji obcí, měst a regionů. Praha: Auditorium.

Kovacs, J. F. (2010): Cultural plan implementation and outcomes in Ontario Canada. Cultural Trends, 19(3), 209-224.

Kovacs, J. F. (2011): Cultural planning in Ontario, Canada: arts policy or more? International Journal of Cultural Policy, 17(3), 321-340.

Kroeber, A. L. - Kluckhohn, C. (1952): Culture. A crtitical review of concepts and definitions. Cambridge, Massachusetss: Peabody Museum.

Landry, C. (2008): Creative City. A Toolkit for Urban Inovators. Second edition. London, Sterling, VA: Comedia.

Marková, B. - Slach, O. (2013): Governance kulturou tažené urbánní regenerace: Př́ípadová studie Černá louka v Ostravě. Sociální Studia/Social Studies, 10(4), 127-143.

Markusen, A. - Gadwa, A. (2010): Arts and Culture in Urban or Regional Planning. Journal of Planning Education and Research, 29(3), 379-391.

Mercer, C. (2002): Toward Cultural Citizenship: Tools for Cultural Policy and Development. (online). http://ssrn.com/abstract $=2153304$.

Miles, M. (2005): Interruptions: Testing the Rhetoric of Culture Led Urban Development. Urban Studies, 42(5/6), 889-911.

MK (2009): Státní kulturní politika na léta 2009-2014. Praha: Ministerstvo kultury ČR.

MMR (2006): Strategie regionálního rozvoje České republiky. Praha: Ministerstvo pro místní rozvoj ČR.

MMR (2010): Zásady urbánní politiky. Praha: Ministerstvo pro místní rozvoj ČR.

MMR (2013a): Koncepce státní politiky cestovního ruchu v České republice na období 2014-2020. Praha: Ministerstvo pro místní rozvoj.

MMR (2013b): Strategie regionálního rozvoje ČR 2014-2020. Praha: Ministerstvo pro místní rozvoj ČR.

Mockovčiaková, A. (2006): Analýza vývoje decentralizace rozhodování o kultuře $v$ České republice po roce 1993 se zaméřením na analýzu vlivu reformy veřejné správy na strukturu výdajů veřejných rozpočtù v oblasti kultury (zaměrení na oblast mistní a regionální kultury). Praha: NIPOS.

MŽP (2004): Strategie udržitelného rozvoje České republiky. Praha: Ministerstvo životního prostředí.

MŽP (2010): Strategický rámec udržitelného rozvoje České republiky. Praha: Ministerstvo životního prostř̌dí ČR.

Patočková, V. - Čermák, D. - Vojtíšková, K., eds. (2012): Kultura v krajich České republiky. Praha: Sociologický ústav AV ČR, v.v.i.

OSN (1992): Rio Declaration on Environment and Development. (online). http://www.jus.uio.no/lm/environmental.development.rio.declaration.1992/portrait.a4.pdf.

OSN (2013): Resolution UN, 20. 12. 2013, A/RES/68/223. (online).

Putnam, R. (2000): Bowling Alone. New York: Simon \& Schuster.

Rowe, J. (2012): What's Your Story? Cultural Mapping - Best Practices Manual for Rediscovering Small Town Canada. Wawa Cultural Mapping Project.

Sedláčková, M. (2012): Dưvěra a demokracie. Přehled sociologických teorií důverry od Tocquevilla po transformaci v postkomunistických zemích. Praha: Sociologické nakladatelství (SLON).

Soukup, V. (2000): Přehled antropologických teorií kultury. Praha: Portál.

Soukup, V. (2011): Antropologie: Teorie člověka a kultury. Praha: Portál.

Soukup, V. (2012): Pražská kulturologická škola. Culturologia 1(1): 12-19.

Stevenson, D. (2004): ,Civic gold` Rush: Cultural planning and the politics of the Third Way. International Journal of Cultural Policy, 10(1), 119-31.

Stevenson, D. (2005): Cultural planning in Australia: Texts and contexts. The Journal of Arts Management, Law, and Society, 35(1), 36-48. 
Stevenson, D. - Rowe, D. - McKay, K. (2010): Convergence in British Cultural Policy: The social, the cultural, and the economic. The Journal of Arts Management, Law, and Society, 40(4), 248-265.

Stewart, S. (2010): Cultural Mapping Toolkit. Vancouver: Creative City Network of Canada, 2010 Legacies Now.

Teaiwa, K. - Mercer, C. (2011): Pacific Cultural Mapping, Planning and Policy Toolkit. Secretariat of the Pacific Community.

Tittlebachová, Š. (2011): Turismus a veřejná správa. Praha: Grada.

Tylor, E. B. (1871): Primitive Culture: Researches into the Development of My thology, Philosophy, Religion, Art and Custom. London: John Murray.

UCLG (2004): Agenda 21 for Culture. United Cities and Local Governments - Comittee on culture. (online). http://www.agenda21culture.net/index. $\mathrm{php} / \mathrm{ca} /$ docman/agenda21/212-ag21en.

UCLG (2006): Advice on local implementation of the Agenda 21 for culture. United Cities and Local Governments - Comittee on culture. (online). http://www.lacult.org/docc/DocImplem_en.pdf.

UCLG (2010): Culture: fourth pillar of sustainable development. Policy statement. United Cities and Local Governments - Comittee on culture. (online). http://issuu.com/uclgcglu/docs/9890675406_en_culture fourth_pillar_sustainable_? $=5168798 / 2754732$.

UCLG (2015): Culture 21: Actions. United Cities and Local Governments Comittee on culture. (online). http://www.agenda21culture.net/images/ a21c/nueva-A21C/C21A/C21_015_en.pdf

Vojtíšková, K. - Mička, P. - Poláková, M. - Patočková, V. - Vajdová, Z. (2015): Metodika tvorby koncepčních dokumentů pro rozvoj kultury a podporu cestovního ruchu s využitím participativních prístupi̊. Praha: Sociologický ústav AV ČR, v.v.i.

Vojtíšková, K. (2015): Co je kulturní plánování? Jak lépe pracovat s obecními rozpočty v oblasti kultury. A2 kulturní čtrnáctideník. 11(7), 26-27.

Vojtíšková, K. - Poláková, M. - Patočková, V. (2016): Cultural planning new inspiration for local governments in the Czech context. Journal of Arts Management, Law, and Society 46(1), 22-33.

Williams, R. (1983): Keywords. A vocabulary of culture and society. New York: Oxford University Press.

\section{AUTORKY}

Vojtíšková, Kateřina absolvovala doktorské studium sociologie na Institutu sociálních studií Fakulty sociálních věd UK. Působí v oddělení Lokální a regionální studia SOÚ AV ČR, v.v.i. Zaměřuje se na výzkum a teorii sociálních nerovností a otázek týkajících se vztahů mezi veřejnou politikou, regionálním rozvojem a občanskou participací.

Kontakt: Mgr. Kateřina Vojtíšková, Ph.D., Sociologický ústav AV ČR, v.v.i., 110 00, Praha 1, Jilská 1, e-mail: katerina.vojtiskova@soc.cas.cz

Poláková, Markéta, absolventka Katedry teorie kultury FF UK. Od roku 2012 působí v oddělení Lokální a regionální studia SOÚ AV ČR, v.v.i. Zde se aktuálně zaměřuje na problematiku rozvoje kultury a uchování kulturního dědictví v regionálním prostředí, prostorových vzorců volebního chování a časoprostorovou dynamiku bezdomovectví.

Kontakt: PhDr. Markéta Poláková, Ph.D., Sociologický ústav AV ČR, v.v.i., 110 00, Praha 1, Jilská 1, e-mail: marketa.polakova@soc.cas.cz

Patočková, Věra je absolventkou doktorského studia kulturologie na Ústavu etnologie Filozofické fakulty UK. Absolvovala rovněž studijní program WLRA International Centre of Excellence v Nizozemsku zaměřený na problematiku volného času. Působí v oddělení Lokální a regionální studia SOÚ AV ČR, v.v.i. Zaměřuje se na problematiku veřejné správy na lokální a regionální úrovni, kultury v lokálním a regionálním prostředí a problematiku volného času.

Kontakt: Mgr. Věra Patočková, M.A., Ph.D., Sociologický ústav AV ČR, v.v.i., 110 00, Praha 1, Jilská 1, e-mail: vera.patockova@soc.cas.cz 